\title{
Addition of hydrocolidics in gluten-free bread and replacement of rice flour for sweet potato flour
}

\author{
Vilmara Araújo FRANCO ${ }^{1}$, Lismaíra Gonçalves Caixeta GARCIA², Flávio Alves da SILVA (D)
}

\begin{abstract}
The objective was to elaborate gluten-free bread, using different hydrocolloids and to verify the effect of substitution of rice flour for sweet potato flour (SPF) on the technological and sensory quality of bread. Better results were observed with the use of $2 \%$ carboxymethylcellulose $(\mathrm{CMC})$, without significant difference $(\mathrm{p}>0.05)$ in the sensory evaluation of the samples containing hydrocolloids. Lower specific volume and higher hardness was observed with the addition of CMC and higher levels of SPF. The microbiological evaluation of bread made from the substitution of $25 \%$ rice flour for SPF allowed to establish shelf life of 7 days, with an acceptability index of $80.3 \%$, which is considered high because it is a new product. Regarding the purchase intention, only $2 \%$ of assessors would certainly not buy the product, showing that the addition of hydrocolloids and SPF to gluten-free bread formulations may be an effective alternative for the gluten-intolerant public.
\end{abstract}

Keywords: gluten intolerance; carboxymethylcellulose; xanthan gum.

Practical Application: Study the production of gluten-free bread and the use of hydrocolloids.

\section{Introduction}

Gluten intolerance is a chronic enteropathy caused by the consumption of gluten proteins found in wheat, rye, barley, and oats. Despite the advances in understanding the pathology and the development of therapies, currently, the gluten-free diet has been the only safe and effective treatment for this disease. However, cereal-based products, especially bread, are the main components of the human diet, thus the celiac diet is very restricted and monotonous (Storck et al., 2009).

Several flours have been used for the development of gluten-free products, including rice flour and cassava starch, which are commonly used due to good digestibility, white color, and neutral flavors. In this context, rice flour has hypoallergenic properties due to its low protein content and low level of prolamins (Crockett et al., 2011). However, it is unable to develop a protein network similar to gluten. Therefore, additives such as hydrocolloids, emulsifiers, proteins, gelatinized starch, and enzymes have been used to improve the rheological properties of the dough, structural and texture characteristics, as well as the shelf life of gluten-free breads (Demirkesen et al., 2013; Mahmoud et al., 2013).

Hydrocolloids are food additives with the function of thickening, stabilizing, improving palatability, increasing moisture retention, imparting viscosity, elasticity and giving the desired texture to food. Several studies have shown that increasing dough viscosity improves the gas retention capacity, thus increasing specific volume, and providing crumb with better structural and texture characteristics (Chaisawang \& Suphantharika, 2005, 2006; Del Bem et al., 2011).
Some examples of hydrocolloids to improve gluten-free bread properties include hydroxypropylmethylcellulose, carboxymethylcellulose, locusta, guar and xanthan gums, pectin, and $\beta$-glucan, among others. In general, the hydrocolloids are added at levels ranging from 1 to $4 \%$ (flour base) and the best results in terms of volume and texture were obtained by incorporating 1 to $2 \%$, which can vary depending on the formulation and the processing conditions (Demirkesen et al., 2010; Gambus et al., 2007; Lazaridou et al., 2007).

Sweet potato (Ipomoea batatas Lam) is recognized worldwide as a low glycemic index food (<55) (Björck et al., 2000), which has attracted attention on the development of products containing sweet potato flour (Gopalakrishnan et al., 2011; Jyothi et al., 2012; Menon et al., 2015).

Given the above, the aim of the present study was to make gluten-free bread using the hydrocolloids carboxymethylcellulose (CMC) and xanthan gum in a farinaceous-base rice flour with replacement partial of rice flour for sweet potato flour.

\section{Materials and methods}

\subsection{Materials}

Sweet potato was supplied by the Federal University of Tocantins (UFT) for the production of sweet potato flour (SPF). Rice flour, dried pasteurized egg white, margarine, crystal sugar, dry yeast, and salt were purchased in the local market. The hydrocolloids xanthan gum (XG) and carboxymethylcellulose (CMC) were 
donated by the companies Premier Alimentos LTDA and Fego Alimentos Ltda, respectively.

\subsection{Experimental design}

A completely randomized design (CRD) was used, which consisted of two types of hydrocolloids (carboxymethylcellulose and xanthan gum) with a total dosage level of $2 \%$ in six treatments, with four replicates, totaling 24 experiments, as described by Demirkesen et al. (2013) and by Mezaize et al. (2009). CRD was also used to produce bread made from sweet potato flour, with five treatments and four original replicates, totaling 20 experiments.

\subsection{Formulations}

The percentages of the ingredients used in rice flour bread formulations are shown in Table 1. The best formulation among those containing different levels of rice flour was selected for the replacement of rice flour for sweet potato flour. Table 2 shows the percentages of rice flour and sweet potato flour used in the formulation of gluten-free bread.

\subsection{Bread making}

Bread was produced according to the methodology of Sciarini et al. (2012) with adaptations. Egg white, margarine, sugar, water and hydrocolloid (xanthan gum (XG) and carboxymethylcellulose (CMC)) were homogenized in planetary mixer for four minutes at low speed, then rice flour (or rice flour + sweet potato flour), biological yeast powder and salt were added and homogenized for another five minutes at high speed. The dough was fractionated in portions of $60 \mathrm{~g}$ and subjected to fermentation in a chamber at $25^{\circ} \mathrm{C} \pm 2{ }^{\circ} \mathrm{C}$ and $85 \%$ relative humidity for 30 minutes, in molds

Table 1. Ingredients used in rice flour bread.

\begin{tabular}{lcccccc}
\hline \multirow{2}{*}{ Ingredients (\%) } & \multicolumn{7}{c}{ Formulations } \\
\cline { 2 - 7 } & Control & FB & FC & FD & FE & FF \\
\hline Rice flour & 100 & 100 & 100 & 100 & 100 & 100 \\
Crystal sugar & 12 & 12 & 12 & 12 & 12 & 12 \\
Water & 150 & 150 & 150 & 150 & 150 & 150 \\
Egg White & 10 & 10 & 10 & 10 & 10 & 10 \\
Margarine & 10 & 10 & 10 & 10 & 10 & 10 \\
Dry biological yeast & 6 & 6 & 6 & 6 & 6 & 6 \\
Salt & 2 & 2 & 2 & 2 & 2 & 2 \\
Carboxymethylcellulose & - & - & 2 & 1 & 1.5 & 0.5 \\
Xanthan gum & - & 2 & - & 1 & 0.5 & 1.5 \\
\hline FB = 100\% XG; FC = 100\% CMC; FD = 50\% CMC/50\% XG; FE = 75\% CMC/25\% XG; \\
FF = 25\% CMC/75\% XG. Control = Without addition of gum; XG = xanthan gum; \\
CMC = carboxymethylcellulose.
\end{tabular}

Table 2. Percentages of rice flour and sweet potato flour in gluten-free bread formulations.

\begin{tabular}{ccc}
\hline Experiments & Rice flour (\%) & Sweet potato flour (\%) \\
\hline Control & 100 & - \\
F2 & 75 & 25 \\
F3 & 50 & 50 \\
F4 & 25 & 75 \\
F5 & - & 100 \\
\hline
\end{tabular}

previously greased with margarine and sprinkled with rice flour. After fermentation, the dough was baked in an electric furnace at $180^{\circ} \mathrm{C}$ for 30 minutes. In the two experiments, the loaves were removed from the molds and cooled at room temperature of $25^{\circ} \mathrm{C} \pm 2{ }^{\circ} \mathrm{C}$ for subsequent analysis.

\subsection{Physicochemical determinations}

\section{Specific volume}

For the determination of the specific volume $\left(\mathrm{cm}^{3} \mathrm{~g}^{-1}\right)$ four loaves were weighed for each formulation, with 10 replicates. Then, the volume of each loaf was determined by the displacement of millet seeds, according to the method described by Leonel et al. (2006) and Silva et al. (1998). The specific volume was calculated by the ratio between the mean volume and the mass of the loaves according to Equation 1.

$\mathrm{SV}=\mathrm{v} / \mathrm{p}$

where, $\mathrm{SV}=$ specific volume $\left(\mathrm{mL} \mathrm{g}^{-1}\right) ; \mathrm{p}=$ mass $(\mathrm{g}) ; \mathrm{v}=$ volume $(\mathrm{mL})$.

\section{Texture profile}

For texture analysis, a Texture Analyzer TA-XT Plus (Surrey, England) was used. Four samples of each formulation were evaluated according to the following parameters, as reported by Esteller \& Lannes (2005): 20 mm perspex P/20P cylinder probe, double compression force, test speed $2.0 \mathrm{~mm} / \mathrm{s}$, trigger force $10 \mathrm{~g}$, type auto, post-test speed $10 \mathrm{~mm} / \mathrm{s}$, distance $6.2 \mathrm{~mm}$, with a data acquisition rate of 200 pps.

\section{Color measurements}

The color of bread crust and crumb was measured in a colorimeter (Hunter-Lab, Color Quest II, Reston, USA), with $\mathrm{L}^{*}$ values ranging from 0 (black) to 100 (white), $\mathrm{a}^{*}$ from red $\left(+a^{\star}\right)$ to green $\left(-a^{*}\right)$, and $b^{*}$ from yellow $\left(+b^{*}\right)$ to blue $\left(-b^{\star}\right)$. Ten readings were performed for each repetition, totalizing three repetitions.

\section{Sensory evaluation}

For the sensory evaluation of bread made from rice flour and hydrocolloids, a ranking affective test was carried out at SENAI Vila Canaã School - Goiânia/GO. Fifty non-gluten-intolerant volunteers and bread consumers were selected among, students and school staff to participate in the test. The samples were evaluated on the second day after manufacture. Samples were served in $1.5 \mathrm{~cm}$ thick slices at room temperature $\left(25 \pm 2{ }^{\circ} \mathrm{C}\right)$, coded with three random digits, under white light, together with the evaluation form and potable water for palate cleansing. The texture was evaluated using an increasing order of preference, that is, the number 1 was assigned to the most preferred sample, and the number 6 to the least preferred sample, with the lowest score corresponding to the best preference ranking (Instituto Adolfo Lutz, 2005).

The sensory evaluation of bread made from rice flour replaced by sweet potato flour was carried out using the affective test, 
performed at SENAI Vila Canaã School - Goiânia/GO. For that, 128 volunteers who had nonceliac gluten sensitivity participated in the test. The acceptance test was performed using a 9-point hedonic scale to evaluate the following sensory attributes: crumb structure, color, aroma, flavor, texture, and overall acceptance. The purchase intention was also assessed using a 5-point attitude scale. The acceptability index (AI), was evaluated according to the scores of the acceptance test (Damásio \& Silva, 1996; Dutcosky, 1996). For the calculation, the following mathematical expression was adopted (Equation 2):

$\mathrm{IA}=(\mathrm{A} / \mathrm{B}) \times 100$

where, $\mathrm{A}=$ mean score obtained for the product and $\mathrm{B}=$ maximum score given to the product.

The sensory evaluation was performed after approval by the Research Ethics Committee of UFG with registration number CAAE: 30890214.0.0000.5083.

\subsection{Statistical analysis}

Data were submitted to analysis of variance and the means were compared by the Tukey's test, using Statistical Analysis System (SAS) procedures. Ranking affective test data were analyzed by the Friedmann test using the Newell and Mac Farlane tables, at the $5 \%$ level of significance (Associação Brasileira de Normas Técnicas, 1994). The results of the acceptance and purchase intention tests were analyzed using the software Excel ${ }^{\circ}$.

\section{Results and discussion}

\subsection{Bread made from rice flour and addition of hydrocolloids}

\section{Specific volume}

Significant differences $(\mathrm{p}<0.05)$ were observed for the specific volume among the formulations as shown in Table 3. The formulation without addition of hydrocolloid (control) presented the lowest specific volume, while higher values were observed for the formulations FC and FF, with no significant differences among them ( $p>0.05)$.

Mezaize et al. (2009) obtained specific volume close to $2.50 \mathrm{~cm}^{3} \mathrm{~g}^{-1}$ in bread with the addition of xanthan gum $(0.6 \%)$ and CMC (1\%), without significant differences between them and the control $(p>0.05)$. In this study, a greater increase in the specific volume was observed when compared to the findings of those authors.

Sciarini et al. (2012) studied bread made from rice flour, cassava starch, and full-fat active soy flour, with addition of $75 \%$ water and $0.5 \%$ hydrocolloid, and found lower specific volumes with mean values of $1.86 \mathrm{~cm}^{3} \mathrm{~g}^{-1}$ for xanthan gum, with no differences from the control (without addition of gum), and $2.14 \mathrm{~cm}^{3} \mathrm{~g}^{-1}$ for $\mathrm{CMC}$, which was higher than the control. Whereas the control formulation presented a specific volume of $1.98 \mathrm{~cm}^{3} \mathrm{~g}^{-1}$, a more expressive increase in the specific volume was observed in the formulation with $100 \%$ rice flour. The increase in specific volume for the samples with addition CMC was also observed in the present study, thus it is possible to state that the water content of the formulation interferes with the increase in the specific volume, as well as the type of flour/starch used.

\section{Texture profile}

As shown in Table 3, all formulations containing hydrocolloids resulted in a softer bread when compared to the control (without the addition of hydrocolloids). A similar trend was found for the other parameters evaluated. A significant increase in hardness and chewiness was observed in the formulations with low $\mathrm{CMC}$ concentration (FE) and high xanthan gum (FF) levels. As reported by Bortolotto (2009), when comparing CMC and xanthan gum, the increase or reduction of CMC concentration led to a stronger gel when compared to the gel formed with similar concentrations of both hydrocolloids. This may explain the increase in hardness and chewing in the formulations FE and FF because according to Katzbauer (1998) the gel strength is correlated with the retrogradation phenomenon, that is, the higher the force, the greater the retrogradation, thus leading to higher hardness and chewiness.

Demirkesen et al. (2010) used Chestnut in gluten-free bread formulations and found hardness values close to $3 \mathrm{~N}$ for the control formulation made with $100 \%$ rice flour and without the addition of hydrocolloids. This value was four times lower than that found in this study, probably due to the composition of the rice grain used by the author in question, with lower protein content and higher lipids and fiber contents. In contrast, Hager \& Arendt (2013) found a value of $18.8 \mathrm{~N}$ for the control sample without addition of hydrocolloid, which is higher than the value found in this study, due to the lower amount of water used in that study.

Table 3. Specific volume and Texture profile of gluten-free bread made from rice flour and addition of different hydrocolloids.

\begin{tabular}{lcccccc}
\hline \multirow{2}{*}{ Parameters } & \multicolumn{5}{c}{ Formulations } \\
\cline { 2 - 6 } \multicolumn{1}{c}{ Control } & FB & FC & FD & FE \\
\hline Specific volume $\left(\mathrm{cm}^{3} \mathrm{~g}^{-1}\right)$ & $0.61^{\mathrm{d}} \pm 0.08$ & $2.60^{\mathrm{ab}} \pm 0.15$ & $2.76^{\mathrm{a}} \pm 0.05$ & $2.43^{\mathrm{b}} \pm 0.13$ & $2.48^{\mathrm{bc}} \pm 0.07$ & $2.64^{\mathrm{ab}} \pm 0.10$ \\
Hardness (gf) & $1392.78^{\mathrm{a}} \pm 258.85$ & $110.72^{\mathrm{c}} \pm 17.84$ & $142.73^{\mathrm{c}} \pm 79.24$ & $106.54^{\mathrm{c}} \pm 52.24$ & $417.00^{\mathrm{c}} \pm 19.51$ & $949.76^{\mathrm{b}} \pm 248.59$ \\
Elasticity & $0.47^{\mathrm{a}} \pm 0.01$ & $0.43^{\mathrm{ab}} \pm 0.02$ & $0.44^{\mathrm{ab}} \pm 0.02$ & $0.40^{\mathrm{b}} \pm 0.18$ & $0.40^{\mathrm{b}} \pm 0.03$ & $0.35^{\mathrm{c}} \pm 0.02$ \\
Cohesiveness & $0.80^{\mathrm{a}} \pm 0.01$ & $0.75^{\mathrm{bcd}} \pm 0.02$ & $0.77^{\mathrm{ab}} \pm 0.02$ & $0.72^{\mathrm{cd}} \pm 0.02$ & $0.75^{\mathrm{bc}} \pm 0.02$ & $0.71^{\mathrm{d}} \pm 0.00$ \\
Chewiness (gf. $\mathrm{mm})$ & $1080.93^{\mathrm{a}} \pm 223.42$ & $66.07^{\mathrm{c}} \pm 19.17$ & $104.76^{\mathrm{c}} \pm 68.33$ & $48.11^{\mathrm{c}} \pm 20.12$ & $262.51^{\mathrm{c}} \pm 31.58$ & $600.70^{\mathrm{b}} \pm 178.90$ \\
\hline
\end{tabular}

Control $=$ Without addition of gum; XG = Xanthan gum; $\mathrm{CMC}=$ Carboxymethylcellulose. Means followed by equal letters in the same column do not differ statistically at the $5 \%$ level of significance by the Tukey's test. $\mathrm{FB}=100 \% \mathrm{XG} ; \mathrm{FC}=100 \% \mathrm{CMC}$; $\mathrm{FD}=50 \% \mathrm{CMC} / 50 \% \mathrm{XG} ; \mathrm{FE}=75 \% \mathrm{CMC} / 25 \% \mathrm{XG} ; \mathrm{FF}=25 \% \mathrm{CMC} / 75 \% \mathrm{XG}$. 
As shown in Table 3, hardness varied 791.5\% (among the formulations), and the highest value was observed in the formulation containing the highest xanthan gum concentration and the lowest $\mathrm{CMC}$, in the ratio of 0.75:0.25. In contrast, lower hardness values were observed for the formulation containing equal parts of both gums (0.5:0.5), showing the positive interaction of the two gums, as also observed by Bortolotto (2009).

Alvarez-Jubete et al. (2010) used 0.5\% xanthan gum in a gluten-free bread formulation made from rice flour and potato starch and obtained hardness of approximately $4 \mathrm{~N}$. In this study, the formulation with $2 \%$ xanthan gum presented a value of approximately $1 \mathrm{~N}$, showing that the type of starch directly affects the texture of gluten-free bread. With respect to the hydrocolloid effectiveness, no significant differences were observed for the attribute texture of bread when CMC and xanthan gum were used alone or in $50 \%$ blends.

\section{Color measurements}

As can be seen in Table 4, a significant difference $(\mathrm{p}<0.05)$ was observed for the parameter luminosity for all formulations when compared to the control, with no significant difference between FB and FC ( $p>0.05)$. The addition of gum may lead to a darkening of the bread crust when compared to the control.

The formulation with equal proportions of the two gums (FD) presented a $\mathrm{L}^{*}$ value significantly higher than the other formulations. In general, the higher $\mathrm{L}^{\star}$ values indicate a lighter crust. In relation to the chromaticity parameters $\left(\mathrm{a}^{*}\right.$ and $\left.\mathrm{b}^{*}\right)$ of the crust, all formulations were found in the regions of red and yellow, which corresponds to positive values for both coordinates, resulting in a more golden crust when compared to control.

With respect to the color measurements of the crumb, a greater uniformity was observed for all parameters. As observed in $\mathrm{L}^{*}$ values (luminosity), the crumb was lighter than the crust, and the formulation FB presented the darkest crumb. No significant differences ( $p>0.05)$ were observed for the coordinates $a^{*}$ and $b^{*}$ among the formulations, and bread with the lighter crumb was the most appreciated by consumers.

Figures 1 and 2 show the results of the addition of the hydrocolloids on the gluten-free bread made from rice flour. The formulation without addition of gum (FB) was the most similar to traditional bread (commercially sold). However, the gas formed during fermentation was not retained, occurring a depression in the upper part and crumb, with the presence of large bubbles and characteristics of stretch bread. The formulations containing higher $\mathrm{CMC}$ concentrations exhibited the best crust formation, that is, less deformed, probably due to the ability of CMC to form a network along with starch, with a better and more uniform gas retention.

The formulations with the addition of hydrocolloids showed a significant improvement in the specific volume, texture, and color of bread crust and crumb when compared to the control. Regarding the formulations containing hydrocolloids, although the best results were observed for the sample with $100 \%$ CMC, a sensory evaluation to investigate the consumers' preference is required.

Table 4. Color of gluten-free bread made from rice flour and addition of different hydrocolloids (xanthan gum and carboxymethylcellulose).

\begin{tabular}{|c|c|c|c|c|c|c|}
\hline \multirow{2}{*}{ Formulation } & \multicolumn{3}{|c|}{ Crust } & \multicolumn{3}{|c|}{ Crumb } \\
\hline & $\mathrm{L}^{*}$ & $a^{*}$ & $b^{*}$ & $\mathrm{~L}^{*}$ & $a^{*}$ & $b^{*}$ \\
\hline Control & $60.77^{a} \pm 6.79$ & $5.42^{c} \pm 2.65$ & $21.40^{\mathrm{bc}} \pm 6.22$ & $65.69^{\mathrm{ab}} \pm 3.42$ & $0.45^{\mathrm{b}} \pm 1.43$ & $9.34^{\mathrm{a}} \pm 3.28$ \\
\hline $\mathrm{FB}$ & $37.26^{\mathrm{e}} \pm 3.72$ & $17.08^{b} \pm 2.10$ & $17.24^{\mathrm{d}} \pm 2.22$ & $61.75^{c} \pm 4.68$ & $1.92^{\mathrm{ab}} \pm 3.48$ & $7.67^{\mathrm{a}} \pm 2.53$ \\
\hline $\mathrm{FC}$ & $36.15^{\mathrm{e}} \pm 2.12$ & $18.46^{\mathrm{a}} \pm 0.90$ & $14.10^{\mathrm{e}} \pm 1.63$ & $63.57^{b c} \pm 4.24$ & $1.20^{\mathrm{ab}} \pm 1.01$ & $7.84^{\mathrm{a}} \pm 1.86$ \\
\hline $\mathrm{FD}$ & $51.30^{\mathrm{b}} \pm 3.15$ & $19.28^{\mathrm{a}} \pm 1.76$ & $26.62^{a} \pm 2.01$ & $67.76^{a} \pm 3.38$ & $0.91^{\mathrm{ab}} \pm 2.36$ & $7.83^{a} \pm 5.52$ \\
\hline $\mathrm{FE}$ & $47.20^{c} \pm 8.01$ & $18.76^{\mathrm{a}} \pm 1.74$ & $23.35^{\mathrm{b}} \pm 4.30$ & $67.81^{\mathrm{a}} \pm 2.27$ & $0.95^{\mathrm{ab}} \pm 0.27$ & $7.61^{\mathrm{a}} \pm 0.69$ \\
\hline $\mathrm{FF}$ & $43.15^{\mathrm{d}} \pm 2.75$ & $18.48^{\mathrm{a}} \pm 0.49$ & $19.05^{\mathrm{cd}} \pm 1.02$ & $65.68^{\mathrm{ab}} \pm 7.46$ & $2.53^{\mathrm{a}} \pm 3.32$ & $9.24^{\mathrm{a}} \pm 2.22$ \\
\hline
\end{tabular}

Control = Without addition of gum; XG = Xanthan gum; CMC = Carboxymethylcellulose. Means followed by equal letters in the same column do not differ statistically at the $5 \%$ level of significance by the Tukey's test. FB $=100 \% \mathrm{XG} ; \mathrm{FC}=100 \% \mathrm{CMC} ; \mathrm{FD}=50 \% \mathrm{CMC} / 50 \% \mathrm{XG} ; \mathrm{FE}=75 \% \mathrm{CMC} / 25 \% \mathrm{XG} ; \mathrm{FF}=25 \% \mathrm{CMC} / 75 \% \mathrm{XG}$.

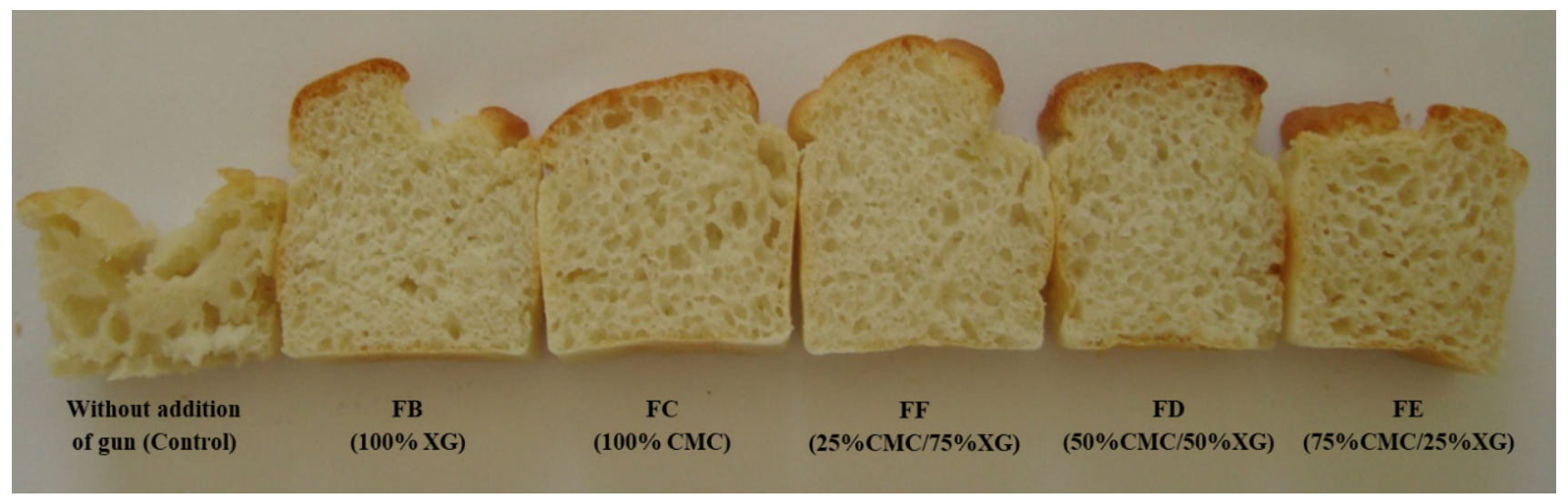

Figure 1. Effect of the application of hydrocolloids on bread crumbs made from rice flour. XG = Xanthan gum; CMC = Carboxymethylcellulose. 


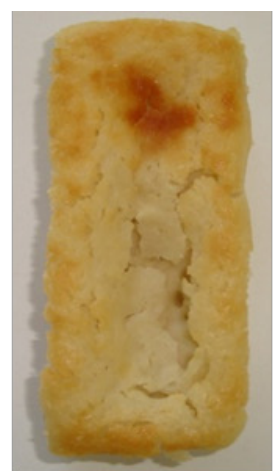

Without addition of gum (control)

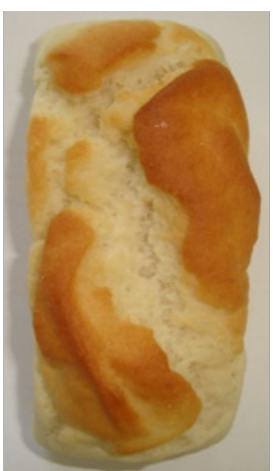

FB

$(100 \% \mathrm{XG})$

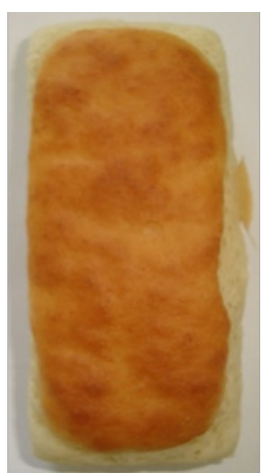

FC

$(100 \% \mathrm{CMC})$

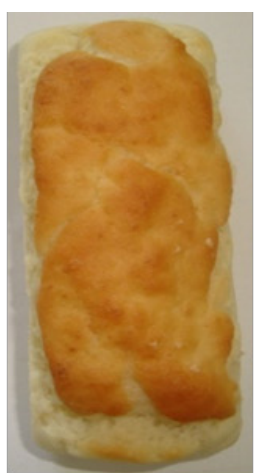

FD

$(50 \% \mathrm{CMC} / 50 \mathrm{XG})$

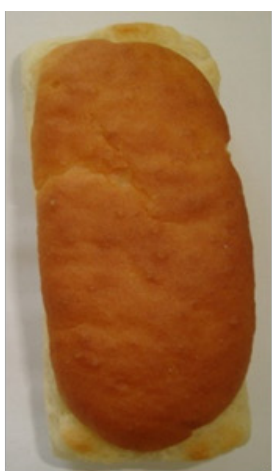

FE

$(75 \% \mathrm{CMC} / 25 \% \mathrm{XG})(25 \% \mathrm{CMC} / 75 \% \mathrm{XG})$

Figure 2. Effect of the application of hydrocolloids on the crust of breads made from rice flour. XG = Xanthan gum; CMC = Carboxymethylcellulose.

\section{Sensory evaluation of bread made from rice flour}

The sensory test was applied to select the formulation with the best preference for the addition of the hydrocolloids. Six gluten-free bread formulations with the addition of two hydrocolloids and a control formulation were analyzed, and the results are shown in Table 5.

As observed in Table 5, a significant difference $(\mathrm{p}<0.05)$ in texture was observed for the control sample (without the addition of hydrocolloid) when compared to the other formulations. From the sensory point of view, no significant differences were observed between the hydrocolloids at the $5 \%$ level of significance.

Therefore, it can be inferred that gluten-free bread with $100 \%$ CMC showed the best behavior for the hydrocolloids tested. No sensory differences were detected between the samples when compared to the control (without the addition of gum). These results demonstrate the possibility of using hydrocolloids in gluten-free formulations, once no differences were detected in the sensory evaluation.

\subsection{Effect of replacement of rice flour for sweet potato flour}

Based on the best formulation for use of hydrocolloids, bread formulations were made according to the methodology described in Sections 2.1 and 2.2, with the replacement of rice flour by sweet potato flour.

\section{Specific volume}

As shown in Table 6, a significant difference was observed in the specific volume of the control, F2 and F5, with no differences for F3 and F4 ( $p>0.05)$. The control (100\% FA) presented the highest specific volume $\left(2.65 \mathrm{~cm}^{3} \mathrm{~g}^{-1}\right)$, while the formulation F2 (with 25\% substitution of rice flour for sweet potato flour) presented the best results among the replacement levels $\left(2.29 \mathrm{~cm}^{3} \mathrm{~g}^{-1}\right)$. The results suggest an interaction between the fiber from sweet potato flour and the components of the formulations, resulting in a decrease in specific volumes with the increase in sweet potato flour.
Table 5. Ranking preference test of gluten-free bread control, FB, FC, $\mathrm{FD}, \mathrm{FE}$, and FF.

\begin{tabular}{cc}
\hline Difference in sum of orders & Difference modules \\
\hline Control - FB & $143(\mathrm{~s})$ \\
Control - FC & $149(\mathrm{~s})$ \\
Control - FD & $133(\mathrm{~s})$ \\
Control - FE & $132(\mathrm{~s})$ \\
Control - FF & $121(\mathrm{~s})$ \\
FB - FC & $6(\mathrm{~ns})$ \\
FB - FD & $10(\mathrm{~ns})$ \\
FB - FE & $11(\mathrm{~ns})$ \\
FB - FF & $22(\mathrm{~ns})$ \\
FC - FD & $16(\mathrm{~ns})$ \\
FC - FE & $17(\mathrm{~ns})$ \\
FC - FF & $28(\mathrm{~ns})$ \\
FD - FE & $1(\mathrm{~ns})$ \\
FD - FF & $12(\mathrm{~ns})$ \\
FE - FF & $11(\mathrm{~ns})$ \\
\hline
\end{tabular}

$(\mathrm{s})=$ significant; $(\mathrm{ns})=$ not significant; MSD $($ minimum significant difference $)=54$. Friedman rank sum test at $5 \%$ of probability $(\mathrm{p}<0.05)$. Control $=$ Without addition of gum; $\mathrm{XG}=$ Xanthan gum; $\mathrm{CMC}=$ Carboxymethylcellulose. $\mathrm{FB}=100 \% \mathrm{XG} ; \mathrm{FC}=100 \%$ $\mathrm{CMC} ; \mathrm{FD}=50 \% \mathrm{CMC} / 50 \% \mathrm{XG} ; \mathrm{FE}=75 \% \mathrm{CMC} / 25 \% \mathrm{XG} ; \mathrm{FF}=25 \% \mathrm{CMC} / 75 \% \mathrm{XG}$.

Trejo-González et al. (2014) evaluated the effect of replacing wheat flour by sweet potato flour in breads, adding up to $20 \%$ sweet potato flour, and observed that the higher the percentage of flour the smaller the specific volume, with a reduction of $12 \%$, mainly due to the lower amount of gluten in the formulation. According to Bojňanská et al. (2012), the decrease in the amount of gluten leads to a lower gas retention capacity during dough fermentation, reducing the specific volume. In the present study, the replacement of up to $100 \%$ rice flour for sweet potato flour led to a reduction of $54 \%$ of the specific volume, while the replacement of $25 \%$ led to a reduction of $13.5 \%$, which is similar to the findings by those authors.

\section{Texture profile}

As can be seen in Table 6, the control ( $0 \%$ SPF) and F2 (25\% SPF) were not significantly different for all texture parameters. The replacement of rice flour for sweet potato flour 
Table 6. Texture profile of gluten-free bread made from rice flour and sweet potato flour and their blends.

\begin{tabular}{|c|c|c|c|c|c|}
\hline \multirow{2}{*}{ Parameters } & \multicolumn{5}{|c|}{ Formulations } \\
\hline & Control & F2 & F3 & $\mathrm{F} 4$ & F5 \\
\hline Specific volume $\left(\mathrm{cm}^{3} \mathrm{~g}^{-1}\right)$ & $2.65^{\mathrm{a}} \pm 0.17$ & $2.29^{\mathrm{b}} \pm 0.11$ & $1.82^{\mathrm{c}} \pm 0.09$ & $1.63^{\mathrm{c}} \pm 0,11$ & $1.21^{\mathrm{d}} \pm 0.18$ \\
\hline Hardness (gf) & $131.39^{c} \pm 31.19$ & $328.47^{\mathrm{c}} \pm 82.89$ & $822.26^{\mathrm{b}} \pm 154.45$ & $1007.40^{\mathrm{b}} \pm 121.79$ & $1835.99^{\mathrm{a}} \pm 356.82$ \\
\hline Elasticity & $0.436^{\mathrm{a}} \pm 0.04$ & $0.393^{\mathrm{ab}} \pm 0.04$ & $0.397^{\mathrm{ab}} \pm 0.05$ & $0.368^{b} \pm 0.04$ & $0.401^{\mathrm{ab}} \pm 0.07$ \\
\hline Cohesiveness & $0.76^{\mathrm{a}} \pm 0.04$ & $0.687^{\mathrm{ab}} \pm 0.05$ & $0.672^{b} \pm 0.06$ & $0.626^{b} \pm 0.06$ & $0.647^{b} \pm 0.09$ \\
\hline Chewiness (gf mm) & $97.78^{c} \pm 19.94$ & $225.84^{c} \pm 64.85$ & $538.05^{\mathrm{b}} \pm 145.62$ & $599.57^{\mathrm{b}} \pm 66.11$ & $1141.80^{\mathrm{a}} \pm 309.37$ \\
\hline
\end{tabular}

Means followed by equal letters in the same column do not differ statistically at the $5 \%$ level of significance by the Tukey's test. Control $=100 \%$ RF; F2 $=75 \%$ RF $/ 25 \%$ SPF; F3 $=50 \%$ $\mathrm{RF} / 50 \% \mathrm{SPF} ; \mathrm{F} 4=25 \% \mathrm{RF} / 75 \% \mathrm{SPF} ; \mathrm{F} 5=100 \% \mathrm{SPF} . \mathrm{RF}=$ rice flour; $\mathrm{SPF}=$ sweet potato flour.

resulted in a progressive increase in the texture profile of the formulations studied.

Trejo-González et al. (2014) also found an increase of $117 \%$ in hardness of bread made with the substitution of $20 \%$ wheat flour for sweet potato flour, with a value of $3.20 \mathrm{~N}$. In the present study, the formulation F2 (25\% SPF) showed an increase in hardness of $150 \%$, with a value of $3.28 \mathrm{~N}$.

Evangelho et al. (2012) studied the technological and nutritional properties of bread made from different rice flour and extruded rice flour ratios, and found hardness value of $2 \mathrm{~N}$ for the control containing only rice flour and sour tapioc starch, while the samples containing $10 \%$ and $25 \%$ of the blends presented hardness higher than $10 \mathrm{~N}$. When the percentage of extruded rice flour (up to $75 \%$ ) was increased, hardness decreased to $2 \mathrm{~N}$, with a negative effect on the crumb structure, with formation of large bubbles and bread deformation. Those authors evaluated the texture of bread and observed that the control sample stored for 120 hours reached a hardness of 28 N. Esteller et al. (2004) reported that the increase in hardness of bread during storage is due to the starch retrogradation and water reduction in the dough after cooking.

In this study, the texture was evaluated on the second day after manufacture (48 hours), with values lower than those found by Evangelho et al. (2012) in the 24-hour storage, showing that the flour blend studied may be an interesting alternative.

The use of rice flour in bread formulations affected the texture when compared to the sweet potato flour, which can be verified by RVA of both flours. Although rice flour had a greater tendency to retrogradation, it has the capacity to harden the bread crumb during storage, while the sweet potato flour provides a softer bread, with crumbling characteristics. Concerning the chewability, the greater the sweet potato flour levels, the higher the chewability.

\section{Color measurements}

Table 7 shows the color measurements of both the control and bread made from sweet potato flour. No significant differences $(p>0.05)$ were observed between the control and the formulations F3 and F5 for the crust luminosity $\left(\mathrm{L}^{*}\right)$, with values closer to zero, representing lighter crusts. This result shows that the addition of $100 \%$ sweet potato flour did not result in darkening of the bread crust when compared to the control formulation (100\% rice flour), which was not observed for F2 (25\% SPF) and F4 (75\% SPF), which were darker than the control.

In relation to the chromaticity parameters $\left(a^{*}\right.$ and $\left.b^{*}\right)$ of the crust, all formulations were in the regions of red and yellow, with positive values for both coordinates. For the coordinate $\mathrm{a}^{\star}$, the higher the SPF concentration, the redder the sample. With respect to the coordinate $b^{\star}$, there was no significant difference between the samples containing $50 \%$ and $100 \%$ SPF when compared to the control. In addition, no significant differences were observed between the samples with 25 and 75\% SPF, which differed from the others, with a greater tendency towards yellow color.

In relation to the crumb color, Table 7 shows that the increase in sweet potato flour resulted in a significant decrease in $\mathrm{L}^{*}$ values, that is, darker crumb was observed for the samples containing higher sweet potato flour concentrations. No significant differences ( $\mathrm{p}>0.05$ ) were observed among the formulations F2, F3 and F4, while the formulation F5 (100\% SPF) presented the darkest crust. In relation to the chromaticity parameters $\left(a^{*}\right.$ and $b^{*}$ ) of the bread crumb, a significant difference $(\mathrm{p}<0.05)$ was observed among the formulations, which exhibited darker crumbs with increasing the percentages of sweet potato flour. Although consumers have appreciated wheat bread crumb due to its brightness, this scenario has been changed due to the increased consumption of whole bread. Therefore, bread of the present study can be well accepted and classified as special line bread, which may be an improvement in the quality of bread for gluten intolerants.

Figure 3 shows that the higher the sweet potato flour concentration, the darker the bread crumb. Concerning the gas retention, a crumb formation with well distributed alveoli was observed up to $50 \%$ replacement level, while the formulations containing from $75 \%$ sweet potato flour exhibited a non-uniform alveolus, indicating that the higher the SPF concentration, the lower gas retention, impairing alveoli formation, specific volume, and texture of the bread crumbs. Figure 4 shows the effect of replacing rice flour for sweet potato flour on bread crust, with an aspect of dehydrated bread, presenting cracks in the upper part.

The results of dietary fiber levels (control, 0.67\%; F2, 0.94\%; F3, 1.20\%; F4, 1.47\%; and F5,1.73\%) showed that the higher the SPF concentration, the higher the fiber contents. It is known that higher fiber contents require a greater amount of water in 
Table 7. Color measurements of gluten-free bread made from rice flour and sweet potato flour and their blends.

\begin{tabular}{|c|c|c|c|c|c|c|}
\hline \multirow{2}{*}{ Formulations } & \multicolumn{3}{|c|}{ Crust } & \multicolumn{3}{|c|}{ Crumb } \\
\hline & $\mathrm{L}^{*}$ & $a^{*}$ & $\mathrm{~b}^{*}$ & $\mathrm{~L}^{*}$ & $a^{*}$ & $\mathrm{~b}^{*}$ \\
\hline Control & $42.18^{\mathrm{c}} \pm 2.30$ & $17.43^{\mathrm{a}} \pm 1.23$ & $18.01^{\mathrm{b}} \pm 1.55$ & $62.64^{\mathrm{a}} \pm 2.4$ & $0.69^{c} \pm 1.36$ & $8.18^{\mathrm{d}} \pm 2.48$ \\
\hline $\mathrm{F} 2$ & $46.89^{\mathrm{ba}} \pm 2.86$ & $16.49^{\text {ba }} \pm 1.27$ & $22.94^{\mathrm{a}} \pm 1.45$ & $54.75^{\mathrm{b}} \pm 3.79$ & $3.14^{c} \pm 2.84$ & $12.90^{c} \pm 3.23$ \\
\hline $\mathrm{F} 4$ & $49.44^{\mathrm{a}} \pm 1.52$ & $13.64^{c} \pm 5.03$ & $22.68^{\mathrm{a}} \pm 1.22$ & $55.26^{\mathrm{b}} \pm 1.38$ & $3.55^{\mathrm{cb}} \pm 0.50$ & $15.14^{\mathrm{bc}} \pm 0.86$ \\
\hline F5 & $42.12^{c} \pm 4.65$ & $12.33^{c} \pm 3.68$ & $17.69^{b} \pm 2.27$ & $45.93^{c} \pm 7.04$ & $11.84^{\mathrm{a}} \pm 4.25$ & $18.40^{\mathrm{a}} \pm 3.66$ \\
\hline
\end{tabular}

Means followed by equal letters in the same column do not differ statistically at the $5 \%$ level of significance by the Tukey's test. Control $=100 \%$ RF; F $2=75 \%$ RF $/ 25 \%$ SPF; F $=50 \%$ $\mathrm{RF} / 50 \% \mathrm{SPF} ; \mathrm{F} 4=25 \% \mathrm{RF} / 75 \% \mathrm{SPF} ; \mathrm{F} 5=100 \% \mathrm{SPF} . \mathrm{RF}=$ rice flour; SPF = sweet potato flour.

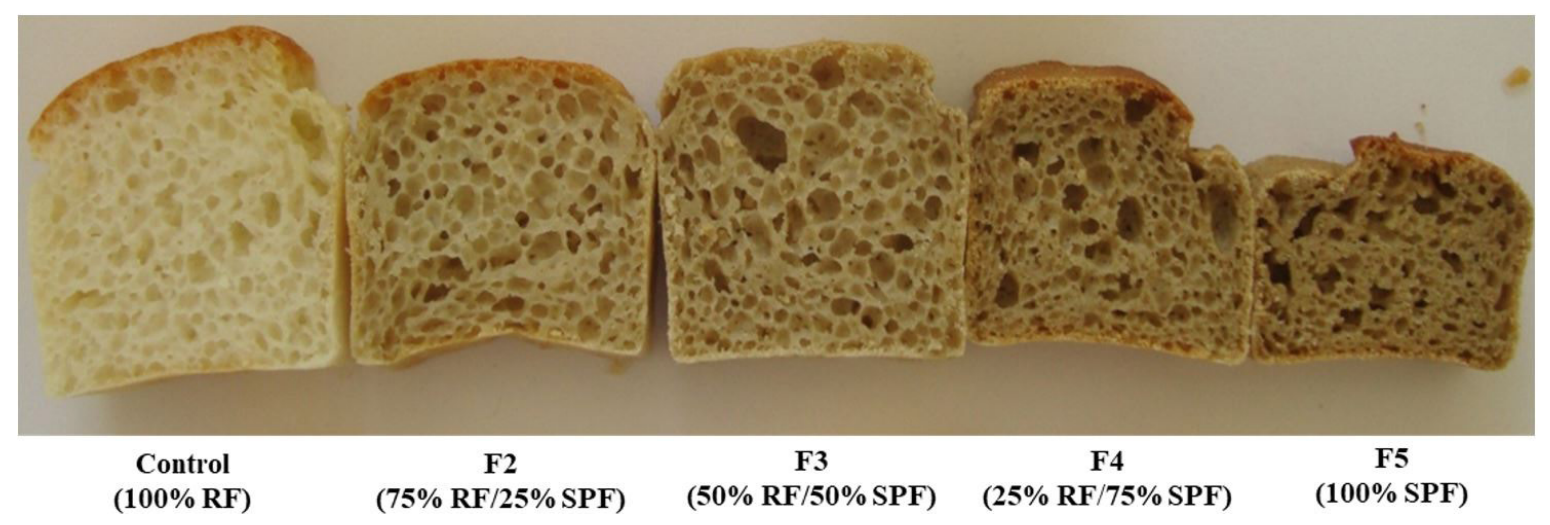

Figure 3. Effect of substitution of rice flour for sweet potato flour in the crust of the loaves. RF = rice flour; SPF $=$ sweet potato flour.

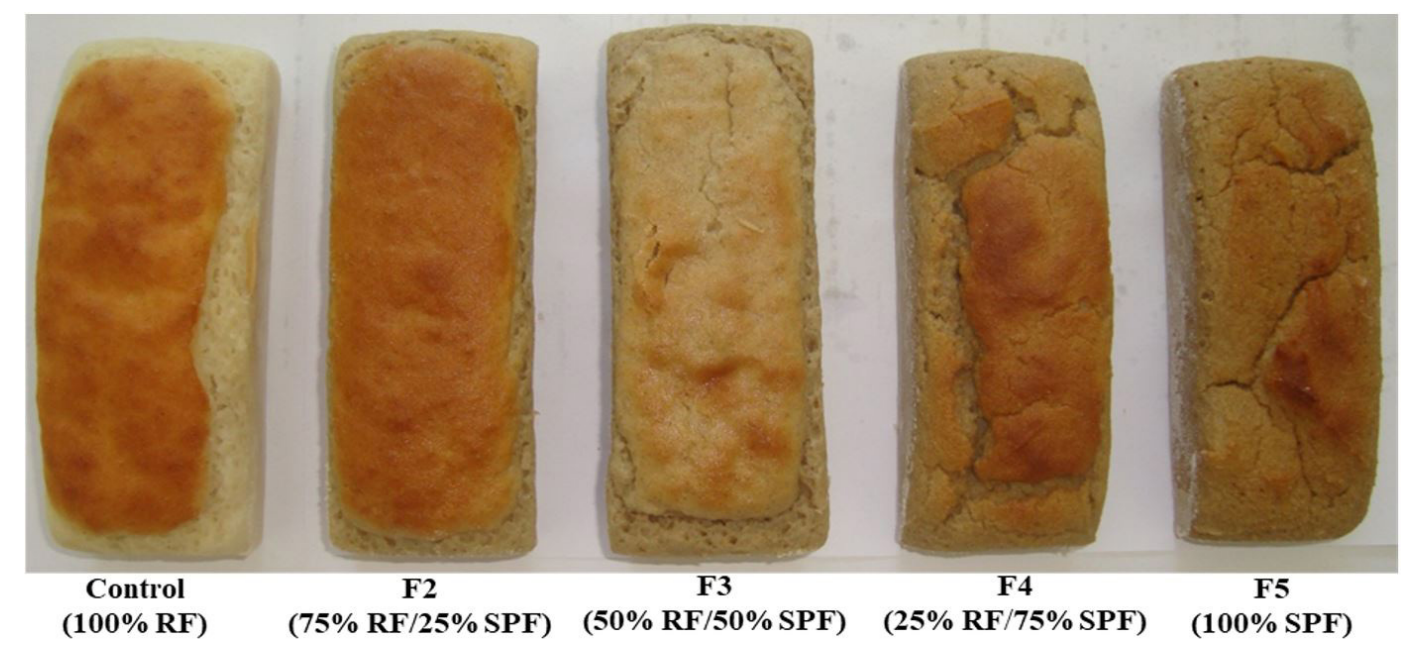

Figure 4. Effect of substitution of rice flour for sweet potato flour on the general modeling of bread. RF = rice flour; SPF $=$ sweet potato flour.

the dough. Thus, since the addition of water was the same for all formulations, increasing the percentage of sweet potato flour may have produced bread with a more dry appearance and a smaller specific volume.

\section{Acceptance test}

The acceptance test was performed for the formulation F2 (25\% replacement of RF for SPF), and the acceptance scores are shown in Table 8. As shown in Table 8, the formulation F2 presented better results for the attribute aroma, followed by color, texture, crumb structure, and flavor. For the aroma attribute, the scores were allocated between the terms "liked moderately" and "liked very much".

It was observed that bread made from SPF presented a darker color when compared to the bread produced with white flour, which may have interfered in the consumers' acceptance, who usually associates the darker bread with whole products. The acceptability index (AI) was $80.3 \%$, considered high because 
Table 8. Mean values $(n=128)$ and standard deviation of the sensory acceptance scores of bread made from sweet potato flour and rice flour blend (75\% RF/25\% SPF).

\begin{tabular}{cc}
\hline Sensory atributes & $\begin{array}{c}\text { Scores (mean } \pm \text { standard } \\
\text { deviation) }\end{array}$ \\
\hline Crumb structure & $6.95 \pm 1.75$ \\
Color & $7.49 \pm 1.41$ \\
Aroma & $7.77 \pm 1.14$ \\
Flavor & $6.84 \pm 1.81$ \\
Texture & $7.02 \pm 1.77$ \\
Overall acceptance & $7.30 \pm 1.60$ \\
\hline
\end{tabular}

Table 9. Purchase intention of bread.

\begin{tabular}{lc}
\hline \multicolumn{1}{c}{ Purchase intention } & Percentage (\%) \\
\hline Certainly would buy & 30 \\
Probably would buy & 33 \\
Maybe would buy /Maybe would not buy & 26 \\
Probably would not buy & 9 \\
Certainly would not buy & 2 \\
\hline
\end{tabular}

it was a new product development. According to Dutcosky (1996), AI $>70 \%$ represents a good acceptance profile.

According to the purchase intention, as shown in Table 9, only $2 \%$ assessors would certainly not buy bread made from sweet potato flour, while $30 \%$ assessors would buy this gluten-free bread if it were for sale. This low purchase rate can be due to the use of sweet potato flour since consumers are not used to consumption of this product.

\section{Conclusion}

Among the hydrocolloids tested in this study, carboxymethylcellulose (CMC) exhibited better results. It was possible to produce bread with uniform crumb and acceptable hardness and chewability with the addition of up to $25 \%$ sweet potato flour to the formulations. The formulation with $25 \%$ sweet potato flour and $75 \%$ rice flour showed the best results when compared to the control sample ( $100 \%$ rice flour).

The microbiological evaluation of bread made from the substitution of rice flour for sweet potato flour allowed to establish a shelf life of 7 days of storage. An acceptability index of $80.3 \%$ was observed for the replacement of $25 \%$ rice flour for sweet potato flour.

\section{References}

Alvarez-Jubete, L., Auty, M., Arendt, E. K., \& Gallagher, E. (2010). Baking properties and microstructure of pseudocereal Xours in gluten-free bread formulations. European Food Research and Technology, 230(3), 437-445. http://dx.doi.org/10.1007/s00217-009-1184-z.

Associação Brasileira de Normas Técnicas - ABNT. (1994). ABNT: NBR 13170 - Teste de ordenação em análise sensorial. Rio de Janeiro: ABNT.

Björck, I., Liljeberg, H., \& Ostman, E. (2000). Low glycaemic-index foods. British Journal of Nutrition, 83(Suppl 1), 149-155. http:// dx.doi.org/10.1017/S0007114500001094. PMid:10889806.
Bojňanská, T., Frančáková, H., Líšková, M., \& Tokár, M. (2012). Legumes - the alternative raw materials for bread production. Journal of Microbiology, Biotechnology and Food Sciences, 1, 876-888.

Bortolotto, D. F. J. (2009). Estudo do comportamento da viscosidade de sistemas de carboximetilcelulose de sódio e diferentes componentes nos produtos para indústria alimentícia (Trabalho de Conclusão de Curso). Faculdade de Ciências, Universidade Estadual Paulista "Júlio de Mesquita Filho", Bauru.

Chaisawang, M., \& Suphantharika, M. (2005). Effects of guar gum and xanthan gum additions on physical and rheological properties of cationic tapioca starch. Carbohydrate Polymers, 61(3), 288-295. http://dx.doi.org/10.1016/j.carbpol.2005.04.002.

Chaisawang, M., \& Suphantharika, M. (2006). Pasting and rheological properties of native and anionic tapioca starches as modified by guar gum and xanthan gum. Food Hydrocolloids, 20(5), 641-649. http:// dx.doi.org/10.1016/j.foodhyd.2005.06.003.

Crockett, R., Ie, P., \& Vodovotz, Y. (2011). How do xanthan and hydroxypropyl methylcellulose individually affect the physicochemical properties in a model gluten-free dough. Journal of Food Science, 76(3), E274-E282. http://dx.doi.org/10.1111/j.1750-3841.2011.02088.x. PMid:21535827.

Damásio, M. H., \& Silva, M. A. A. P. (1996). Curso de treinamento em análise sensorial. Campinas: Fundação Tropical de Tecnologia "André Tosello". Apostila.

Del Bem, M. S., Polesi, L. F., \& Sarmento, S. B. S. (2011). Propriedades funcionais de amido de leguminosas em associação à hidrocoloides. Boletim CEPPA, 29(1), 103-116. http://dx.doi.org/10.5380/cep. v29i1.22763.

Demirkesen, I., Mert, B., Sumnu, G., \& Sahin, S. (2010). Rheological properties of gluten-free bread formulations. Journal of Food Engineering, 96(2), 295-303. http://dx.doi.org/10.1016/j.jfoodeng.2009.08.004.

Demirkesen, I., Sumnu, G., \& Sahin, S. (2013). Quality of gluten-free bread formulations baked in different ovens. Food and Bioprocess Technology, 6(3), 746-753. http://dx.doi.org/10.1007/s11947-0110712-6.

Dutcosky, S. D. (1996). Análise sensorial de alimentos. Curitiba: Champagnat.

Esteller, M. S., \& Lannes, S. C. S. (2005). Parâmetros complementares para fixação de identidade e qualidade de produtos panificados. Ciência e Tecnologia de Alimentos, 25(4), 802-806. http://dx.doi. org/10.1590/S0101-20612005000400028.

Esteller, M. S., Amaral, R., \& Lannes, S. C. S. (2004). Effect of sugar and fat replacers on the texture of baked goods. Journal of Texture Studies, 35(4), 383-393. http://dx.doi.org/10.1111/j.1745-4603.2004. tb00602.x.

Evangelho, J. A., Pinto, V. Z., Zavareze, E., Da, R., Vanier, N. L., Dias, A. R. G., \& Barbosa, L. M. P. (2012). Propriedades tecnológicas e nutricionais de pães preparados com diferentes proporções de farinha de arroz extrusada. Revista Brasileira de Agrociência, 18, 264-282.

Gambus, H., Sikora, M., \& Ziobro, R. (2007). The effect of composition of hydrocolloids on properties of gluten-free bread. Acta Scientiarum Polonorum, 6, 61-74.

Gopalakrishnan, J., Menon, R., Padmaja, G., Sajeev, M. S., \& Moorthy, S. N. (2011). Nutritional and functional characteristics of protein fortified pasta from sweet potato. Food and Nutrition Sciences, 2(09), 944-955. http://dx.doi.org/10.4236/fns.2011.29129.

Hager, A. S., \& Arendt, E. K. (2013). Influence of hydroxypropylmethylcellulose (HPMC), xanthan gum and their combination on loaf specific volume, crumb hardness and crumb grain characteristics of gluten-free 
breads based on rice, maize, teff and buckwheat. Food Hydrocolloids, 32(1), 195-203. http://dx.doi.org/10.1016/j.foodhyd.2012.12.021.

Instituto Adolfo Lutz - IAL. (2005). Normas analíticas do Instituto Adolfo Lutz: métodos químicos e físicos para análise de alimentos (4. ed.) Brasília: IAL.

Jyothi, G. K., Renjusha, M., Padmaja, G., Sajeev, M. S., \& Moorthy, S. N. (2012). Evaluation of nutritional and physico-mechanical characteristics of dietary fiber enriched sweet potato pasta. European Food Research and Technology, 234(3), 467-476. http://dx.doi. org/10.1007/s00217-011-1657-8.

Katzbauer, B. (1998). Properties applicantions of xanthan gum. Polymer Degradation \& Stability, 59(1-3), 81-84. http://dx.doi.org/10.1016/ S0141-3910(97)00180-8.

Lazaridou, A., Duta, D., Papageorgiou, M., Belc, N., \& Biliaderis, C. G. (2007). Effects of hydrocolloids on dough rheology and bread quality parameters in gluten-free formulations. Journal of Food Engineering, 79(3), 1033-1047. http://dx.doi.org/10.1016/j.jfoodeng.2006.03.032.

Leonel, M., Mischan, M. M., Pinho, S. Z., Iaturo, R. A., \& Duarte, J. Fo. (2006). Efeitos de parâmetros de extrusão nas propriedades físicas de produtos expandidos de inhame. Food Science and Technology (Campinas), 26(2), 459-464. http://dx.doi.org/10.1590/S010120612006000200033.

Mahmoud, R. M., Yousif, E. I., Gadallah, M. G. E., \& Alawneh, A. R. (2013). Formulations and quality characterization of gluten-free Egyptian balady flat Bread. Annals of Agricultural Science, Cairo, 58(1), 19-25. http://dx.doi.org/10.1016/j.aoas.2013.01.004.
Menon, R., Padmaja, G. S., \& Sajeev, M. (2015). Cooking behavior and starch digestibility of NUTRIOSE ${ }^{\bullet}$ (resistant starch) enriched noodles from sweet potato flour and starch. Food Chemistry, 182, 217-223. http://dx.doi.org/10.1016/j.foodchem.2015.02.148. PMid:25842330.

Mezaize, S., Chevallier, S., Le Bail, A., \& De Lamballerie, M. (2009). Optimization of gluten-free formulations for French-style breads. Journal of Food Science, 74(3), 140-146. http://dx.doi.org/10.1111/ j.1750-3841.2009.01096.x. PMid:19397719.

Sciarini, L. S., Ribotta, P. D., Leon, A. E., \& Perez, G. T. (2012). Incorporation of several additives into gluten free breads: effect on dough properties and bread quality. Journal of Food Engineering, 111(4), 590-597. http://dx.doi.org/10.1016/j.jfoodeng.2012.03.011.

Silva, M. R., Silva, M. A. A. P., \& Chang, Y. K. (1998). Utilização da farinha de jatobá (Hymenaea stigonocarpa Mart.) na elaboração de biscoitos tipo cookie e avaliação de aceitação por testes sensoriais afetivos univariados e multivariados. Food Science and Technology (Campinas), 18(1), 25-34. http://dx.doi.org/10.1590/S010120611998000100007.

Storck, C. R., Pereira, J. M., Pereira, G. W., Rodrigues, A. O., Gularte, M. A., \& Dias, A. R. G. (2009). Características tecnológicas de pães elaborados com farinha de arroz e transglutaminase. Brazilian Journal of Food Technology, 02, 71-77. http://dx.doi.org/10.1590/19816723.6014

Trejo-González, A. S., Loyo-González, A. G., \& Munguía-Mazariegos, M. R. (2014). Evaluation of bread made from composite wheat-sweet potato flours. International Food Research Journal, 21, 1683-1688. 